\title{
O projeto assimilacionista português: o diretório pombalino sob um olhar decolonial
}

\author{
The portuguese assimilation project: the pombaline directory under a \\ decolonial glance
}

\section{El directorio pombalino y el proyecto asimilacionista portugués: una mirada decolonial}

\section{Valéria Maria Santana Oliveira'}

Universidade Tiradentes (Unit), Diretoria de Educação a Distância, Professora Adjunta

\section{Ilka Miglio de Mesquita ${ }^{2}$}

Universidade Tiradentes (Unit), Programa de Pós-graduação em Educação, Professora

Resumo: A questão indígena no Brasil é permeada por inúmeras idas e vindas. Desde o período colonial, têm sido criadas, revogadas e recriadas diversas leis que versam sobre os direitos dos índios. Diante disso, o objetivo deste artigo é analisar desdobramentos da legislação indigenista criada pelo Marquês de Pombal: o Diretório dos índios, de 1755, e o Alvará de 1758. Entre outras medidas, esses dispositivos legais impõem a língua portuguesa em detrimento da "língua geral", utilizada pelos jesuítas nos trabalhos pedagógicos e de catequese indígena. Consideramos que, mais do que normas e valores, foi imposta principalmente a cosmovisão do colonizador, e, sobre esse fato, precisamos lançar um olhar decolonial. Para analisar os impactos dessas medidas, apoiamo-nos em Walsh (2013), Carneiro da Cunha (1992), Dantas, Sampaio e Carvalho (1992), Garcia (2007), entre outros. Conforme veremos, o impacto dessas medidas resultou em uma política de assimilacionismo que contribuiu para a hibridação cultural de diversos povos indígenas.

Palavras-chave: Diretório. Catequese indígena. Assimilacionismo. Decolonialidade.

Abstract: The indigenous question in Brazil is permeated by innumerable comings and goings. Since the colonial period various laws have been created, revoked and recreated that deal with the rights of the Indians. The aim of this article is to analyze unfolding of the Indianist legislation created by the Marquis of Pombal: the Indian Directory of 1755 and the License of 1758. Among other measures, these legal provisions impose the Portuguese language to the detriment of the "general language", used by the Jesuits in the teaching and indigenous catechesis. We consider that, more than norms and values,

Doutora em Educação pela Universidade Tiradentes; Mestre em Desenvolvimento e Meio Ambiente pela Universidade Federal de Sergipe; https://orcid.org/0000-0001-7125-4129; http://lattes.cnpq.br/9901368485788985.

2 Doutora em Educação pela Universidade Estadual de Campinas; Mestre em Educação pela Universidade Federal de Uberlândia; https://orcid.org/0000-0002-5071-2415; http://lattes.cnpq.br/4750940229067933. 
the colonizer's worldview has been imposed, and on these facts we need to cast a decolonial glance. For this analysis, we support in Walsh (2013), Carneiro da Cunha (1992), Dantas, Sampaio and Carvalho (1992), Garcia (2007), among others. We will see that the impact of these measures resulted in a policy of assimilationism that contributed to the cultural hybridization of many indigenous peoples.

Keywords: Directory. Indigenous catechesis. Assimilationism. Decoloniality.

Resumen: La cuestión indígena en Brasil está impregnada por innumerables idas y venidas. Desde el período colonial se crean, revocan y recrean diversas leyes que versan sobre los derechos de los indios. En este sentido, el objetivo de este artículo es analizar desdoblamientos de la legislación indigenista creada por el Marqués de Pombal: el Directorio de los indios de 1755 y el Permiso de 1758. Entre otras medidas, estos dispositivos legales imponen la lengua portuguesa en detrimento de la "lengua general", utilizada por los jesuitas en los trabajos pedagógicos y de catequesis indígena. Consideramos que, más que normas y valores, fue impuesta principalmente la cosmovisión del colonizador y, sobre estos hechos, necesitamos echar una mirada decolonial. Para este análisis, apoyamos en Walsh (2013), Carneiro da Cunha (1992), Dantas, Sampaio e Carvalho (1992), Garcia (2007), entre otros. Como veremos, el impacto de esas medidas resultó en una política de asimilacionismo que contribuyó a la hibridación cultural de muchos pueblos indigenas.

Palabras clave: Directorio. Catequesis indigena. Asimilacionismo. Decolonialidad.

Recebido em 05 de agosto de 2017

Aceito em 17 de outubro de 2018

Publicado em 19 de fevereiro de 2019

\section{INTRODUÇÃO}

Quem me dera ao menos uma vez Fazer com que o mundo saiba que seu nome

Está em tudo e mesmo assim Ninguém the diz ao menos obrigado

Mas nos deram espelhos E vimos um mundo doente [...] (íNDIOS, 1986).

A descolonização, sabemo-lo, é um processo histórico, isto é, não pode ser compreendida, não encontra a sua inteligibilidade, não se torna transparente para si mesma senão na exata medida em que se faz discernível o movimento historicizante que lhe dá forma e conteúdo.

(FANON, 1968). 
Longe de ser aqui interpretados com um caráter de vitimização, os versos da música Índios, compostos por Renato Russo na década de 1980, devem nos remeter a uma reflexão sobre os impactos ocasionados pelo processo colonizador instalado na América pelos europeus. Revestida de uma falsa legalidade, a questão indígena no Brasil sempre foi permeada por inúmeras idas e vindas, pois desde o período colonial têm sido criadas, revogadas e recriadas diversas leis que versam sobre os direitos dos índios. Vamos a alguns exemplos: em 30 de agosto de 1609, foi promulgada a lei que declarava livres todos os índios do Brasil, porém, dois anos depois, a escravidão foi restaurada pela lei de 10 de setembro, com a justificativa da guerra justa. Já no século seguinte, ocorreu a extinção legal do cativeiro indígena por meio da lei de 06 de junho de 1755. São estas apenas algumas das leis criadas pelo governo colonial para o controle da população nativa - e suas contradições são visíveis.

Outro aspecto relevante a ser considerado ao tratarmos da questão indígena no Brasil é a política de aldeamentos, ${ }^{3}$ visto que essas povoações criadas a partir da colonização se configuraram em espaços privilegiados para a inserção dos índios na ordem colonial (ALMEIDA, 2010). Para essa integração, os padres europeus, notadamente os jesuítas, estabeleceram um verdadeiro "império" missionário no Brasil entre os séculos XVII e XVIII. Financeiramente independentes e ligados diretamente a Roma, os religiosos da Companhia de Jesus desenvolveram não somente a catequese, mas também o controle da mão de obra indígena nos aldeamentos. Nas missões religiosas, eram aldeados grupos indígenas de línguas e culturas diferentes, o que resultava na elaboração e reelaboração de formas de organização social decorrentes da imposição da religião e do trabalho. Essas práticas influenciaram sobremaneira a hibridação e extinção de boa parte dos aspectos culturais e religiosos de diversos grupos indígenas e promoveram uma política de homogeneização e assimilação, para além dos impactos ocorridos, em razão da proibição do uso das línguas nativas. Não obstante, esses povos sempre encontraram meios de resistir ao domínio do poder colonial, transgredi-lo e subvertê-lo.

Diante disso, e considerando a afirmação de $\mathrm{Fanon}^{4}$ (1968, p. 26), quando este nos adverte que a decolonização só pode ser compreendida quando percebemos com clareza "o movimento historicizante que lhe dá forma e conteúdo", é que se faz necessário compreender

Cumpre esclarecer que há uma diferença entre o significado do termo "aldeia" e "aldeamento". Aldeia é um povoado indígena preexistente à colonização e "aldeamento" é um agrupamento indígena montado pelos missionários, com finalidades específicas. Os aldeamentos foram implantados desde o século XVI a partir do trabalho pioneiro dos jesuítas. 0 regimento de 1686 concedeu a administração espiritual e politica dos aldeamentos às ordens religiosas (BEOZZO, 1983). De acordo com Manuela Carneiro da Cunha, os aldeamentos vão sempre servir a três propósitos: infraestrutura, fonte de abastecimento e reserva de mão de obra. Segundo a autora: "Aldear os índios, ou seja, reuni-los e sedentarizá-los sob governo missionário ou leigo, era prática antiga, iniciada em meados do século XVI. Diziam os jesuítas que se não podia catequizá-los sem esse meio. Quanto aos colonos, desejavam os aldeamentos o mais próximos possível de seus próprios estabelecimentos, já que neles se abasteciam de mão de obra." (CARNEIRO DA CUNHA, 1992, p. 143).

4 Veja-se a epígrafe. 
a política indigenista a partir da ótica do pensamento decolonial. Nesse sentido, o objetivo deste artigo é analisar desdobramentos da legislação indigenista criada pelo Marquês de Pombal: o Diretório dos índios, de 1755, e o Alvará de 1758.

Em suas obras, Quijano (2013), Mignolo (2012) e Walsh (2013) trazem à tona, respectivamente, questões referentes à colonialidade do poder, à opção "descolonial" e à pedagogia decolonial. ${ }^{5}$ Essa perspectiva se faz necessária para uma compreensão mais acurada dos desdobramentos das imposições previstas no Diretório Pombalino, o que não pode ser visto pela ótica de uma possível passividade por parte dos indígenas. Nesse sentido, lançar um olhar decolonial sobre a política indigenista é identificar nesses processos o protagonismo indígena e as diversas formas de resistência ao projeto colonizador, que buscava normalizar a identidade europeia como a única legítima e possível. Essa visão, no entanto, não considerou a capacidade dos povos nativos de encontrar formas de resistir, (re) existir e (re)viver - e, assim, subverter a dominação.

\section{A LEI DO DIRETÓRIO DOS ÍNDIOS}

A partir de 1755, Sebastião José de Carvalho e Melo, Conde de Oeiras e, posteriormente, Marquês de Pombal, inicia um processo de reformulação da política colonial portuguesa e realiza uma série de medidas modernizadoras, entre elas a expulsão dos jesuítas de todas as colônias. As chamadas reformas pombalinas tinham o objetivo primordial de romper a relação entre lgreja e Estado, além de diminuir as dificuldades econômicas pelas quais o governo português passava, especialmente após o terremoto de Lisboa em 1755.

As ideias ilustradas desse déspota esclarecido influenciaram a nova forma de lidar com os índios; nesse contexto, as sedes das missões foram transformadas em vilas ou povoados, ${ }^{6}$ e os índios foram considerados emancipados da autoridade religiosa e submetidos apenas ao governo laico. A lei de 06 de julho de 1755 passou a ser conhecida como "Lei das Liberdades", e sua aplicação foi regulada pelo ato de 03 de maio de $1757,{ }^{7}$ que, inicialmente, destinava-se às povoações dos índios do Pará e Maranhão. Estava posto o "Diretório que se deve observar nas povoações dos índios do Pará e Maranhão, enquanto sua Majestade não mandar o contrário" (ALMEIDA, 1997), conhecido como "Diretório dos Índios" ou, ainda, “Diretório

\footnotetext{
5 Os termos descolonial ou decolonial costumam ser usados indistintamente de acordo com a preferência de cada autor; o peruano Anibal Quijano e o argentino Walter Mignolo, por exemplo, utilizam a grafia descolonial ao passo que Catherine Walsh utiliza a grafia decolonial. Esta última é a nossa opção.

6 De acordo com Flexor (2002, p. 172), "Portugal e Espanha adotaram, no século XVIII, o conceito original de defender o território povoando-o (uti possidetis), estabelecendo alternativas para o desenvolvimento socioeconômico americano."

7 Ato expedido por Mendonça Furtado, governador do Grão-Pará.
} 
Pombalino". Posteriormente, o Alvará de 1758 ordenaria que a liberdade concedida aos índios do Maranhão, para as suas pessoas, bens e comércio, pelos alvarás de 06 e 07 de junho de 1755, fosse estendido da mesma forma a todos os índios que habitavam o Brasil, fato que já esboçava o código que determinaria o tratamento destinado aos indígenas.

0 Diretório Pombalino determinava uma série de atribuições aos chamados "diretores" dos aldeamentos; responsáveis por estabelecer os termos dos contratos de trabalho, eles também deveriam estipular e receber o salário a ser pago sob a alegação de proteger os índios da usura dos colonos (PARAíSO, 2014). Os objetivos do Diretório eram claros: a dilatação da fé, a extinção do gentilismo, a propagação do evangelho, a civilidade dos índios, o bem comum dos vassalos, o aumento da agricultura, a introdução do comércio e o estabelecimento, a opulência e a total felicidade do Estado.

Analisando esses objetivos, Mattos (2012) propõe uma inversão em sua ordem. Segundo o autor:

0 objetivo principal, acreditamos, era o estabelecimento a opulência e a total felicidade do Estado. Afinal, este era o sentido primeiro do governo de Mendonça Furtado: garantir a soberania territorial portuguesa após o Tratado de Madri (1750); ${ }^{8}$ converter o índio em vassalo livre do rei e de Deus, valorizando-o, dessa forma, enquanto elemento estratégico da ocupação do território limítrofe no norte da América portuguesa e como mão de obra indispensável ao sistema colonial, bem como os escravos africanos introduzidos pela Companhia de Comércio. (MATTOS, 2012, p. 52-53).

Assim, declarando que os índios eram livres, ficava garantida a mão de obra, ao mesmo tempo que também eram introduzidos escravos africanos por meio da Companhia de Comércio do Grão-Pará. Outro aspecto importante da lei do Diretório foi a imposição da língua portuguesa, a "língua do Príncipe", em detrimento da "língua geral", utilizada pelos jesuítas nos trabalhos pedagógicos e de catequese indígena. ${ }^{9}$ Os padres da Companhia de Jesus utilizavam como metodologia de ensino a organização de uma gramática, utilizando o tupiguarani como "língua geral"; com isso, abarcavam as "línguas profanas aqui encontradas." (SANTOS, 2010). Em suma, podemos destacar os seguintes pontos principais do Diretório: o fim da discriminação legal dos índios, com a extinção das diferenças entre índios e brancos; o estímulo à miscigenação biológica por meio de casamentos mistos; a determinação de que

\footnotetext{
80 Tratado de Limites de Madri, de 1750, desencadeou uma série de ações do governo luso com relação a seu Reino. Até o Tratado de Santo lldefonso, de 1777, sucederam-se fatos importantes que transformaram as feições de uma parcela do Reino português: o território do Brasil (FLEXOR, 2006, p. 1).

9 Souza (2010, p. 282) explica melhor essa questão da língua geral: "Praticamente não se falava português no Brasil colônia, mas sim a chamada 'língua da costa' ou 'língua geral', uma variante do tupi antigo, meio de comunicação entre clérigos, colonos e indigenas." Com o passar do tempo, a língua geral se dividiu em dois ramos: a amazônica e a meridional. No século XIX, a primeira transformou-se na língua Nheengatu (NAVARRO, 2012).
} 
filhos gerados dessas uniões seriam considerados mais capacitados que os brancos para ocupar cargos administrativos nas aldeias; a proibição de chamarem os índios de "negros da terra"; a transformação dos indígenas em súditos portugueses, como os demais colonos; a reprodução da prática de cooptar lideranças para formar elites indígenas.

Essa suposta preferência pelos índios para a ocupação de cargos administrativos nas aldeias não deve de modo algum ser compreendida como um reconhecimento da capacidade dos índios; ao contrário, o Diretório determinava que, por serem rústicos, ignorantes e sem aptidão para o governo, deveriam ficar sob a tutela de um diretor, que atuaria como o administrador das aldeias e dirigiria todas as atividades dos aldeados (ALMEIDA, 2010). Dessa forma, é possivel compreender que o suposto fim das discriminações entre brancos e índios ocorrera apenas na letra da lei, visto que não correspondia à prática dos colonos, que continuaram explorando a mão de obra indígena.

Muitas vezes os diretores das aldeias eram os próprios missionários católicos enviados para aldear os índios e, em razão da escassez de padres, acumulavam várias funções. Tornar-se diretor de uma aldeia não tinha apenas por objetivo ensinar, mas também ser instrumento eficaz de colaboração com o projeto de colonização e dominação arquitetado pelos europeus. No entanto, como veremos, esse projeto de dominação e suas implicações continuaram a se perpetuar, tendo como um dos seus principais instrumentos a educação.

\section{A LEGISLAÇÃO INDIGENISTA E A EDUCAÇÃO ESCOLAR INDÍGENA}

Algumas determinações presentes no Diretório denotam a crença de que a utilização da língua portuguesa contribuía para a civilização dos índios, pois a "língua do Príncipe" seria a base da civilidade e deveria, portanto, ser ensinada. Nesse intento, a lei determinava que deveriam ser criadas em todos os aldeamentos duas escolas, uma para meninas e outra para meninos, cujo ensino deveria ser condizente com as especificidades de cada sexo. Neste contexto, o catecismo configurava-se "um dispositivo fundamental no processo de escolarização e como método de ensino das primeiras letras." (OLIVEIRA et al., 2010).

Essa determinação não foi seguida em todo o território, ${ }^{10}$ no entanto denota a mentalidade da época quanto à educação de meninas e meninos indígenas. No Regimento ficava claro que os objetivos a serem alcançados com as meninas eram dois: a aptidão na

10 A política indigenista pombalina foi aplicada de formas diferentes a depender do contexto - local ou povos. Uma experiência de tradução dessa legislação para a realidade local foi a elaboração das "Instruções para o governo dos índios da Capitania de Porto Seguro", estudadas por Cancela (2013). 
língua portuguesa - não sendo permitido falarem o guarani - e o aprendizado de todos os serviços domésticos necessários ao bom funcionamento de uma casa. Já com relação aos meninos, as expectativas eram um pouco mais amplas: eles deveriam fazer sua higiene pessoal ao acordar e após o almoço; teriam de ficar das oito às 11 horas na escola, onde aprenderiam a falar, ler e escrever em português, além de aprender a rezar e argumentar (GARCIA, 2007a).

Essas diferenças quanto à educação das crianças indígenas devem nos remeter, ainda, a outro aspecto pouquíssimo abordado na historiografia dos índios, a saber, a mulher indígena. Apesar da recente postura revisionista da historiografia indígena, pouco se tem pesquisado sobre as índias, principalmente com base na ótica delas próprias. Como afirma Julio (2015, p. 1-2):

\footnotetext{
Diversos estudos têm buscado sublinhar a historicidade dos índios, superando estereótipos ainda muito fortes - e não apenas no senso comum - que os apresentam como meras vitimas dos processos de colonização. Tais estereótipos incidem com mais força sobre as mulheres indigenas, que continuam objeto de poucos estudos, principalmente historiográficos.
}

É sabido que nem sempre se faz possivel para os historiadores vislumbrar, por meio dos vestígios que restaram do passado, quais foram as atuações distintas e/ou papéis desempenhados pelas mulheres indígenas. No entanto, há que se considerar que cada sociedade indígena possui aspectos culturais próprios, e que, em muitas delas, a organização social era matriarcal. Além disso, algumas funções que, sob o olhar europeu e eurocêntrico, deveriam ser desempenhadas por homens, em alguns grupos indígenas eram exclusivas das mulheres. Quanto a isso, Melatti (2014) explica que em muitas sociedades cabe às mulheres a atividade coletora; em outras, somente elas podem fazer os cestos de palha ou determinadas pinturas corporais. Assim, é possível compreender que a divisão sexual do trabalho varia bastante na forma como ocorre entre as várias sociedades indígenas, o que certamente foi mais um motivo de estranhamento por parte do colonizador.

Diante desses elementos, as diferenças de tratamento impostas a meninas e meninos indígenas, mais do que representativas da mentalidade colonial, o são certamente das formas de tratamento dispensadas às mulheres e meninas indígenas. Essas diferenças ficam bastante claras na concepção de educação pensada para elas presente na legislação em tela. Nessas escolas havia, ainda, segundo Garcia (2007a), a constante vigilância para que os pequenos indígenas não falassem mais sua língua nativa a fim de incorporarem cotidiana e definitivamente a língua portuguesa. 0 Regimento era taxativo quanto a isso, previa, inclusive, castigos para quem falasse a língua guarani e o perdão para quem delatasse os desobedientes. 
Por outro lado, apesar dessas imposições, os idealizadores do Diretório parecem ter desconsiderado dois aspectos muito importantes: o primeiro deles é que as crianças chegavam às escolas com cerca de seis anos de idade, ou seja, já falavam e se comunicavam em seu idioma tribal; o segundo é que elas continuavam tendo contato com suas famílias, que, em sua maioria, não falavam o português. Dessa forma, as meninas e os meninos indígenas, em vez de abandonar o idioma guarani, tornaram-se bilíngues, pois precisavam se comunicar com seus parentes.

Para além desses dois pontos, é importante considerar, ainda, que o tempo de permanência nas escolas não deveria ser longo, pois, assim que as crianças aprendessem a ler, escrever, rezar e falar português (no caso dos meninos, aprender a contar também), deveriam deixar a escola para dar lugar a outras. Esses são elementos que demonstram diversas falhas na legislação quanto ao objetivo de imposição da "língua do Príncipe" às crianças indígenas.

\section{LÍNGUA E IDENTIDADE}

Além de tornar obrigatório o uso da língua portuguesa, a Lei do Diretório também teve como característica relevante a ideia de transformar os índios em vassalos do rei, em pé de igualdade jurídica com os demais colonos. Foi, ainda, preocupação do legislador determinar igualdade no tratamento, que deveria ser distinto daquele dado aos escravos negros:

\footnotetext{
Não consentirão os Diretores, daqui por diante, que pessoa alguma chame Negros aos Índios nem que estes usem entre si esse nome como até agora o faziam para que, compreendendo que lhes não compete a vileza do mesmo nome, possam conceber aquelas nobres ideias que naturalmente infundem nos homens a estimação e a honra."
}

É possível identificar no texto da legislação a mentalidade da época no que diz respeito às raças e ao entendimento da existência de gradações quanto aos estágios de evolução dos tipos humanos. No topo dessa escala encontrava-se, evidentemente, o europeu; no segundo nível, encontrava-se o índio; e, em último lugar, o negro. Tornar os índios vassalos do rei foi, dessa forma, uma estratégia de D. José I para ocupar, efetivamente, as terras conquistadas, determinando, em tese, que os índios recebessem o mesmo tipo de tratamento 
destinado ao colonizador; assim, estes não poderiam se identificar (nem ser identificados) no mesmo patamar dos africanos, declaradamente considerados inferiores.

Essa legislação trouxe, ainda, segundo Garcia (2007b), implicações na identidade dos índios, pois, ao proibir-lhes de falar seu idioma nativo, acabou por comprovar a relação existente entre idioma, cultura e identidade, por chamar atenção para a importância da língua como elemento identitário. Afirma a autora:

Assim, ao proibir a língua "nativa" e instalar mecanismos de coerção para que os índios falassem o português, a aplicação do Diretório foi na contramão dos objetivos dos seus mentores. Em detrimento de lograr uma integração e homogeneização étnica e cultural, reforçou fronteiras e demonstrou que os costumes não são tão fáceis de ser erradicados. (GARCIA, 2007a, p. 109, grifo do autor).

Quanto a essa relação entre língua e identidade - e analisando a história do processo colonizador europeu - fica evidente que um dos aspectos comuns é a imposição de uma única língua nacional. Essa estratégia busca a fixação de uma identidade, a normalização identitária. No caso em tela, o Diretório impunha mais do que a utilização de uma língua, mas a própria identidade portuguesa, à qual os nativos deveriam se adequar. Ao analisar a relação entre poder e identidade, Silva (2014, p. 83) afirma que:

Fixar uma determinada identidade como a norma é uma das formas
privilegiadas de hierarquização das identidades e das diferenças. A
normalização é um dos processos mais sutis pelos quais o poder se
manifesta no campo da identidade e da diferença. Normalizar significa
eleger - arbitrariamente - uma identidade específica como o parâmetro
em relação ao qual as outras identidades são avaliadas e hierarquizadas.
Normalizar significa atribuir a essa identidade todas as características
positivas possíveis, em relação às quais as outras identidades só podem
ser avaliadas de forma negativa.

Partindo desse entendimento, tornar os índios vassalos do rei era mais do que garantir os domínios portugueses por conta do Tratado de Madri, mas, e acima de tudo, impor valores, culturas e normas consideradas superiores. Assim, mais do que a imposição de normas e valores, foi imposta principalmente a cosmovisão do colonizador, que, ao criar um sistema no qual os nativos tinham de abrir mão da possibilidade de expressar sua cultura, tentou restringir-lhes a possibilidade de transmitir aos seus descendentes sua própria visão de mundo, o que podemos chamar de uma forma de "imperialismo ideológico".

Portanto, colonizar o índio foi colonizar também (e principalmente) a sua cultura, em que a chamada "civilização ocidental" acabou por exercer um imperialismo ideológico cujos 
desdobramentos permanecem até a atualidade. Neste sentido, Nobre (2015, p. 28), em sua tese, afirma, entre outros aspectos, que os estudos pós-coloniais passaram a dar ênfase à "interação bilateral entre o colonizador e o colonizado e ao consequente caráter híbrido da identidade dos envolvidos nesta interação, como resultado das trocas socioculturais inerentes a ela."

Quanto à questão da língua, é sabido que hoje diversos povos indígenas perderam completamente seus idiomas, fato que desencadeou iniciativas de vários grupos para a revitalização do Nheengatu, também conhecido como Tupi Moderno, assim como de diversas outras línguas indígenas, por meio de projetos de ensino das línguas, do teatro e da criação de escolas bilíngues. ${ }^{12}$ Podemos compreender a partir dessas ações o que Walsh (2013) denomina de pedagogias decoloniais, na qualidade de estratégias, práticas e metodologias de organização e ação, empregadas para subverter a dominação colonial, que ainda se encontra presente na atualidade, em virtude de toda uma cultura baseada no pensamento etnocêntrico. Como afirma a autora em outra obra:

Son gritos que llaman, imploran y exigen un pensar-sentir-hacer-actuar, que claman por prácticas no solo de resistir sino también de in-surgir, prácticas como pedagogías-metodologías de creación, invención, configuración y coconstrucción - del qué hacer y cómo hacer - de luchas, caminares y siembras dentro de las fisuras o grietas del sistema capitalista-moderno/ colonial-antropocéntrico-racista-patriarcal. (WALSH, 2017, p. 30).

Ou seja, é a busca por práticas de resistência, mas também de insurgência; são pedagogias-metodologias de criação, invenção, configuração e co-construção de lutas, caminhadas e semeaduras, por entre as frestas do sistema capitalista-moderno/colonialantropocêntrico-racista-patriarcal.

\section{CASAMENTOS INTERÉTNICOS E ASSIMILACIONISMO}

As medidas de Pombal estimularam as uniões interétnicas, a assimilação dos indígenas pela sociedade branca e, sobretudo, a obrigatoriedade do ensino da língua portuguesa para os nativos. Essa legislação dava aos indígenas total liberdade para "dispor livremente de suas pessoas e de seus bens" (AMOROSO, 1992, p. 306); no entanto, os índios se sujeitavam a um trabalho que era oficialmente remunerado, mas na prática era escravista

12 Exemplos disso são os casos dos Guató, no Mato Grosso; dos Terena, no Mato Grosso do Sul; dos Krahô e Krahô-Kanela, de Tocantins; e dos Munduruku, em Manaus, entre outros. 
(MENÉNDEZ, 1992), tendo em vista que, legalmente, os indígenas eram livres, já que as leis previam o estabelecimento de uma taxa, os modos de pagamento e o tempo de serviço. No entanto, a liberdade era violada, o prazo estipulado desobedecido e os salários não eram pagos, havendo vários indícios, segundo Perrone-Moisés (1992, p. 121), de que os índios aldeados ficavam em situação pior do que os escravos: "sobrecarregados, explorados, mandados de um lado para outro sem que sua 'vontade', exigida pelas leis, fosse considerada."

Segundo Amoroso (1992), o Diretório Pombalino de 1755 apoiava-se em dois pilares: a administração militar e os casamentos interétnicos. Havia o incentivo para o estabelecimento de casais europeus ou de europeus casados com mulheres indígenas nas novas vilas criadas por Pombal. Nesses contextos, os contatos com brancos eram constantes, permitidos e estimulados, o que dava continuidade às decorrências funestas das missões religiosas. Como afirma Oliveira (1998, p. 57):

\footnotetext{
Se as missões - enquanto produto de políticas estatais - conjugavam aspectos que podemos chamar de assimilacionistas e preservacionistas, o seu sucedâneo histórico - o "diretório de índios" - pendeu decisivamente para a primeira direção, estimulando os casamentos interétnicos e a fixação de colonos brancos dentro dos limites dos antigos aldeamentos.
}

A presença de colonos nos aldeamentos era justificada pelos missionários como bastante útil, visto que serviriam de exemplo de catolicismo e trabalho para os índios, além de se constituírem em uma pedagogia do exemplo edificante, para que os índios aprendessem convivendo com a "gente católica e trabalhadora do Brasil." (AMOROSO, 2014, p. 103).

No entanto, nem sempre o que consta na lei atinge seus objetivos. Em Goiás, por exemplo, o sistema do Diretório encontrou resistência dos índios, que fugiam para o mato, atacavam o gado nas fazendas e também as cidades mineiras. Diante disso, o governo reagiu e autorizou guerras de conquista para combater os "índios hostis" (KARASCH, 1992). Considere-se, ainda, a postura de alguns diretores, que, com seus desmandos e abusos, contrariava princípios do Diretório, fato que motivou não só a revolta dos índios, mas também diversas denúncias da parte destes.

Percebemos, a partir desses aspectos, que o Diretório foi crucial para o estímulo à miscigenação e ao projeto português de assimilação da população indígena; observem-se, na transcrição da lei, as importantes recomendações aos diretores dos aldeamentos:

Entre os meios mais proporcionados para se conseguir tão virtuoso, útil e santo fim, nenhum é mais eficaz que procurar por via de casamentos esta importantíssima união, pelo que recomendo aos Diretores que apliquem um incessante cuidado em facilitar e promover pela sua parte os matrimônios 
entre os Brancos e os Índios, para que por meio deste sagrado vinculo se acabe de extinguir totalmente aquela odiosíssima distinção, que as nações mais polidas do mundo abominaram sempre como inimigo comum do seu verdadeiro e fundamental estabelecimento. (ALMEIDA, 1997). ${ }^{13}$

Dessa forma, os diretores não eram orientados apenas a aceitar os casamentos interétnicos, mas a estimulá-los. Como podemos conferir em outro trecho da lei:

\begin{abstract}
Para facilitar os ditos matrimônios, empregarão os Diretores toda a eficácia do seu zelo em persuadir a todas as Pessoas Brancas, que assistirem nas suas Povoações, que os Índios tanto não são de inferior qualidade a respeito delas, que, dignando-se Sua Majestade de os habilitar para todas aquelas honras competentes às graduações dos seus postos, consequentemente ficam logrando os mesmos privilégios as Pessoas que casarem com os ditos índios, desterrando-se por este modo as prejudicialissimas imaginações dos Moradores deste Estado, que sempre reputaram por infâmia semelhantes matrimônios. (ALMEIDA, 1997). ${ }^{14}$
\end{abstract}

Outra estratégia de assimilação foi o regime de compadrio, visto que, por meio do batismo, os índios tinham de adotar nomes cristãos, sendo, muitas vezes, índios já convertidos que faziam as vezes de padrinhos. Essa foi, portanto, uma estratégia utilizada para a consolidação dos primeiros laços entre os cativos e a sociedade escravista (MONTEIRO, 2005).

É possivel perceber que as políticas e estratégias assimilacionistas resultaram em forte hibridismo cultural, o que é compreensível, tendo em vista que as identidades não são puras nem estáticas, mas sempre resultado de encontros por vezes conflituosos. $\mathrm{Na}$ perspectiva da teoria cultural contemporânea, hibridismo seria "a mistura, a conjunção, o intercurso entre diferentes nacionalidades, entre diferentes etnias, entre diferentes raças." № caso dos indígenas, são processos de hibridização (ou hibridação) forçada, fruto de relações conflituosas ligadas a "histórias de ocupação, colonização e destruição." (SILVA, 2014, p. 87).

Para além das implicações trágicas das imposições previstas no Diretório Pombalino, é importante considerar que muitos povos indígenas souberam usar estratégias de negociação para atuar em um contexto de exploração e proibições, utilizando a legislação para proveito próprio, ${ }^{15}$ pois, em meio às ações de exploração da mão de obra indígena e das perdas resultantes desse processo, os nativos não deixaram de agir, nem de reagir. Em muitos casos, optaram por

13 Texto digitado a partir das cópias dos originais publicadas em Almeida (1997), disponível em http://www.nacaomestica.org/ diretorio_dos_indios.htm.

14 Texto digitado a partir das cópias dos originais publicadas em Almeida (1997), disponivel em http://www.nacaomestica.org/ diretorio_dos_indios.htm.

T5 Exemplo disso está na pesquisa de Garcia (2007b), especificamente quando a autora trata da aldeia de Nossa Senhora dos Anjos. 
se submeterem aos aldeamentos para garantir a sobrevivência, em detrimento da escravização, o que não significava aceitar essa condição passivamente. Nesse sentido, Almeida (2010) afirma que muitos chefes indígenas, principalmente em contextos de guerra, chegavam a dispor de considerável poder de barganha. Dessa forma, é possível perceber que o protagonismo indígena se fazia presente, na medida em que estabeleceram táticas e formas de negociação que lhes favoreciam. Exemplo disso são os casos em que os próprios solicitavam missionários para os aldeamentos, conforme é descrito por Dantas (1991, p. 35):

\begin{abstract}
Embora possa parecer estranho que os índios tomassem a iniciativa de pedir missionários ao governador da Bahia, ou que chefes indigenas tenham ido ao encontro de jesuítas convidando-os para irem às suas aldeias iniciativas registradas em documentos da época - parece-nos que essa busca de missionários, além da curiosidade que os padres despertavam, era uma estratégia adotada pelos índios na tentativa de escaparem à escravização realizada pelos colonos.
\end{abstract}

Assim, apesar de boa parte da documentação ter sido produzida por não indígenas, a partir da perspectiva do pensamento decolonial, é possível vislumbrar o protagonismo indígena fazendo uso de seus conhecimentos e capacidade de negociação. Almeida (2017, p. 25) destaca, ainda, que nos séculos XVl e XVII havia uma grande dependência dos portugueses em relação aos índios, o que fez com que a colonização dependesse, em grande medida, das dinâmicas locais: "Dinâmicas essas que incluem as ações dos povos subalternos, tais como indígenas, africanos e seus descendentes, como a história indígena e a história da escravidão estão revelando." No exemplo citado por Dantas (1991), a busca pela catequese se configurava em uma tática para permanecerem a salvo da escravização, visto que a legislação da época não permitia a venda de indígenas catequizados.

Um aspecto que merece destaque ao pensarmos nos desdobramentos do projeto colonial português é que os indígenas do Nordeste - região onde a colonização teve início - possuem uma história diferenciada em relação aos que habitam outras regiões do País. Isso ocorre pelo fato de essa região ter sofrido um processo de miscigenação mais intenso, posto que, em decorrência da colonização, e com o reforço das determinações do Diretório, os nativos foram adquirindo uniões interétnicas com europeus, como também com africanos e afrodescendentes. Já no século XIX quase todos os povos indígenas dessa região viviam em aldeamentos ou já tinham passado por esse processo, a exemplo do aldeamento de São Pedro, em Sergipe, conforme descrito por Gardner (1942, p. 104): ${ }^{16}$

160 naturalista escocês George Gardner (1810-1849) esteve no Brasil entre 1836 e १८41, dedicando-se especialmente à exploração de áreas de cerrado e caatinga no interior do País. Embora de interesse eminentemente botânico, o relato de suas viagens - Travels in the interior of Brazil, publicado originalmente em 1846 - contém preciosas informações sobre os costumes das populações com as quais esteve em contato. Em suas viagens, Gardner esteve em contato direto com duas tribos indígenas: 
0 número das familias que habitam a itha sobe a cerca de 40 e são, em maior parte, índios civilizados. Na tarde de nossa chegada apresentei-me ao seu capitão [cacique], homem já velho, trajando calças de algodão grosso, camisa do mesmo pano, chapéu e sandálias de couro. Estava sentado debaixo de um zyzyphus, a concertar uma rede de pesca. Dele soube que os índios da itha, estão diminuindo gradualmente de número. 0 velho suspirou ao dizer-me que não vinha longe o dia em que sua raça estaria extinta ou pelo menos amalgamada com os outros habitantes.

Ao analisar esse relato poderíamos concluir que as populações aldeadas estariam em uma situação tal que não lhes restou a mínima possibilidade de reação ante a opressão sofrida. No entanto, como já exposto anteriormente quando citamos o protagonismo indígena, há registros que evidenciam a atuação de índios aldeados em diferentes circunstâncias, seja participando de movimentos armados ou mesmo reivindicando junto às autoridades o cumprimento das leis (DANTAS; SAMPAIO; CARVALHO, 1992).

\footnotetext{
Concebê-los como bastiões renitentes da resistência ao avanço colonizador, ou como ingênuos contumazes, acarreta uma outra supressão. Pois, além da eliminação fisica - a qual foi responsável pelo desaparecimento de uma parcela considerável daquelas populações - assunções como essas promovem uma distorção da memória histórica relativa aos índios que não corresponde às suas ações. (COELHO, 2006, p. 119-120).
}

Os índios são, portanto, agentes históricos, e não considerar isso equivale a uma compreensão equivocada de que eles seriam meros fantoches manipulados pelos colonizadores.

\section{6 ÚLTIMAS CONSIDERAÇÕES}

Contrariando a previsão pessimista (ou realista?) do velho cacique citado por George Gardner, desde a década de 1970 os povos indígenas têm aumentado numericamente. Por meio de estratégias e alianças, boa parte desses povos tem conseguido o reconhecimento de sua identidade e a conquista efetiva dos direitos previstos na Constituição Federal. Exemplo disso é a história dos índios Xokó, do Estado de Sergipe; assim como ocorrido em 
outras partes do Brasil, tanto a catequese quanto a posterior espoliação de suas terras desencadearam um processo sistemático de genocídio e etnocídio contra o qual os Xokó conseguiram resistir. No entanto, boa parte da população desconhece a existência desse grupo, ao passo que outros não acreditam que eles sejam índios "legítimos", visto que moram em casas de alvenaria, têm pele escura e não falam mais sua língua materna.

Diante de trajetórias como a dos índios Xokó, fazem-se claramente perceptíveis os diversos desdobramentos do histórico de contatos entre índios e europeus, que ora os utilizavam como guias, ora como mão de obra, mas sempre como instrumentos para seus interesses econômicos e políticos. Todas essas ações tiveram o respaldo das diversas políticas indigenistas, sempre justificadas pela ideia de "civilizar" os índios - seja por meio da religião, da escola, da língua, seja por meio da imposição de costumes e valores, além do incentivo à miscigenação.

Entre as várias políticas indigenistas implantadas ao longo da História do Brasil, discorremos aqui sobre o Diretório Pombalino, que foi revogado pela Carta Régia de 12 de maio de 1798, após vigorar por 43 anos. Em um primeiro momento, este pode ser considerado um curto espaço de tempo, no entanto as repercussões dessa legislação se estenderam pelos séculos seguintes, mesmo porque, como não houvesse outra que a substituísse de imediato, seus princípios (do Diretório) acabaram por continuar vigentes na prática. Após a revogação do Diretório, somente em 1845 novas diretrizes foram estabelecidas por meio do Decreto $n$. 426, de 24 de julho de 1845 ("Regulamento acerca das missões de catechese e civilização dos índios"), que prolongou o sistema de aldeamento, entendido como uma transição para a assimilação completa dos índios.

Podemos perceber que a questão indígena já foi alvo de diversas leis que, na prática, não asseguraram aos índios seus direitos, apenas contribuíram para a ideologia do assimilacionismo e para a hibridação e destruição de boa parte da cultura indígena no Brasil. Os povos indígenas estão hoje fazendo a "viagem da volta", ${ }^{17}$ isto é, estão reconquistando seus territórios e reafirmando suas identidades, visto que as diretrizes do Diretório Pombalino geraram implicações que se fazem presentes ainda na atualidade, pois determinar que os indígenas adotassem a língua portuguesa foi mais do que garantir os domínios portugueses, mas hierarquizar identidades e normalizar a identidade portuguesa (europeia), entendida como a única legítima e possível.

Contudo, apesar de tantas imposições, podemos afirmar que os povos indígenas sempre encontraram meios de subverter a dominação resistindo, (re)existindo e (re)vivendo. 17 Expressão utilizada pelo antropólogo João Pacheco de Oliveira (1998) para explicar a relação entre etnicidade e características
físicas. 


\section{REFERÊNCIAS}

ALMEIDA, M. R. C. de. A atuação dos indigenas na História do Brasil: revisões historiográficas. Revista Brasileira de História, São Paulo, v. 37, n. 75, p. 17-38, maio 2017. Disponível em: http://www.scielo.br/ scielo.php?script=sci_arttext\&pid=S0102-01882017000200017\&lng=en\&nrm=iso. Acesso em: 09 out. 2018.

ALMEIDA, M. R. C. de. Os índios na história do Brasil. Rio de Janeiro: FGV, 2010.

ALMEIDA, R. H. de. 0 diretório dos índios: um projeto de "civilização" no Brasil do século XVIII. Brasília, DF: Editora UnB, 1997. Disponível em: http://www.nacaomestica.org/diretorio_dos_indios.htm. Acesso em: 23 dez. 2015.

AMOROSO, M. R. Corsários no caminho fluvial: os Mura do rio Madeira. In: CARNEIRO DA CUNHA, M. (org.). História dos índios no Brasil. São Paulo: Companhia das Letras, 1992, p. 297-310.

AMOROSO, M. R. Terra de índio: imagens em aldeamentos do império. São Paulo: Terceiro Nome, 2014.

BEOZZO, J. O. Leis e Regimentos das Missões: Política indigenista no Brasil. São Paulo: Loyola, 1983.

CANCELA, F. Recepção e tradução do Diretório dos índios na antiga Capitania de Porto Seguro: uma análise das Instruções para o governo dos índios. Revista História Social, Campinas, v. 2, p. 43-70, 2013.

CARNEIRO DA CUNHA, M. Política indigenista no século XIX. In: CARNEIRO DA CUNHA, M. (org.). História dos índios no Brasil. São Paulo: Companhia das Letras, 1992. p. 133-154.

COELHO, M. C. 0 Diretório dos Índios e as Chefias Indígenas: uma inflexão. Campos, Pará, v. 7, n. 1, p. ११७-१34, 2006.

DANTAS, B. G. Os índios em Sergipe. In: DINIZ, D. M. et al. (coord.). Textos para a História de Sergipe. Aracaju: Universidade Federal de Sergipe/BANESE, 1991. p. 19-60.

DANTAS, B. G.; SAMPAIO, J. A. L.; CARVALHO, M. do R. G. Os povos indígenas no Nordeste brasileiro: um esboço histórico. In: CARNEIRO DA CUNHA, M. (org.). História dos índios no Brasil. São Paulo: Companhia das Letras, 1992. p. 431-456.

FANON, F. Os condenados da terra. Rio de Janeiro: Civilização Brasileira, 1968. (Coleção Perspectivas do homem. Série Política).

FLEXOR, M. H. 0. 0 Diretório dos índios do Grão-Pará e Maranhão e o Direito Indiano. Politeia: História e Sociedade, Vitória da Conquista, v. 2, n. 1, p. 167-183, 2002. Disponível em: http://periodicos.uesb.br/ index.php/politeia/article/viewFile/160/174. Acesso em: 27 dez. 2015. 
FLEXOR, M. H. O. A "civilização" dos índios e a formação do território do Brasil. Histedbr, Campinas, 2006. Disponivel em: http://www.histedbr.fae.unicamp.br/navegando/artigos_frames/artigo_073.html. Acesso em: 26 nov. 2015.

GARCIA, E. F. As diversas formas de ser índio: políticas indígenas e politicas indigenistas no extremo sul da América Portuguesa. 2007. Tese (Doutorado em História) - Programa de Pós-Graduação em História, Universidade Federal Fluminense, Niterói, 2007a.

GARCIA, E. F. 0 projeto pombalino de imposição da língua portuguesa aos índios e sua aplicação na América Meridional. Revista Tempo, Rio de Janeiro, v. 23, p. 23-38, $2007 b$.

GARDNER, G. Viagens no Brasil: principalmente nas províncias do norte e nos distritos do ouro e do diamante durante os anos de 1836-1841. Tradução: Albertino Pinheiro. São Paulo: Companhia Editora Nacional, 1942. (Série Brasiliana, v. 223).

ÍNDIOS. Compositor e intérprete: Renato Russo. In: Dois. Intérprete: Renato Russo. Rio de Janeiro: EMI-Odeon Brasil, 1986. 1 disco vinil (47 min).

JULIO, S. S. Mulheres indígenas na América Latina Colonial. In: SIMPÓSIO NACIONAL DE HISTÓRIA, 28., 2015, Florianópolis. [Anais] [...]. Florianópolis, 2015. Disponivel em: http://www.snh2015.anpuh.org/resources/ anais/39/1439240941_ARQUIVO_Anpuh2015.pdf. Acesso em: 26 jul. 2017.

KARASCH, M. Catequese e cativeiro: Política indigenista em Goiás, 1780-1889. In: CARNEIRO DA CUNHA, M. (org.). História dos índios no Brasil. São Paulo: Companhia das Letras, 1992. p. 397-412.

MATTOS, Y. de. A última inquisição: os meios de ação e funcionamento do Santo Ofício no Grão-Pará pombalino (1750-1774). Jundiái: Paco Editorial, 2012.

MELATTI, J. C. Índios do Brasil. 9. ed. São Paulo: Editora da Universidade de São Paulo, 2014.

MENÉNDEZ, M. A. A área Madeira-Tapajós: situação de contato e relações entre colonizador e indígenas. In: CARNEIRO DA CUNHA, M. (org.). História dos índios no Brasil. São Paulo: Companhia das Letras, 1992. p. 281-296.

MIGNOLO, W. D. Local Histories/Global Designs: Coloniality, Subaltern Knowledges, and Border Thinking. 2. ed. Princetown/0xford: Princetown University Press, 2012.

MONTEIRO, J. M. Negros da terra: índios e bandeirantes nas origens de São Paulo. São Paulo: Companhia das Letras, 2005.

NAVARRO, E. A. 0 último refúgio da língua geral no Brasil. Estudos Avançados, v. 26, n. 76, p. 245-254, 2012.

NOBRE, W. C. de A. História linguística do Sul da Bahia (1534-1940). Tese (Doutorado) - Instituto de Letras, Universidade Federal da Bahia, Salvador, 2015. 
OLIVEIRA, J. P. de. Uma etnologia dos "índios misturados"? Situação colonial, territorialização e fluxos culturais. Mana, v. 1, n. 4, p. 47-77, 1998. Disponivel em: http://www.scielo.br/scielo.php?pid=S0104-93131998000100003\&script=sci_arttext. Acesso em: 29 mar. 2015.

OLIVEIRA, L. E. et al. A legislação pombalina e a história do ensino de línguas no Brasil. In: OLIVEIRA, L. E. et al. (org.). A legislação pombalina sobre o ensino de línguas: suas implicações na educação brasileira (1757-1827). Maceió: EDUFAL, 2010. p. 49-102.

PARAÍSO, M. H. B. 0 tempo da dor e do trabalho: a conquista dos territórios indigenas nos sertões do leste. Salvador: Edufba, 2014.

PERRONE-MOISÉS, B. Índios livres e índios escravos: os princípios da legislação indigenista no período colonial. In: CUNHA, Maria Manuela C. da. (org.). História dos índios no Brasil. São Paulo: Cia. Das Letras, 1992. p. 115-132.

QUIJANO, A. Colonialidade do poder e classificação social. In: SOUSA SANTOS, Boaventura de; MENESES, M. P. (org.). Epistemologias do Sul. São Paulo: Cortez, 2013.

RIBEIRO, E. R. George Gardner entre os índios do sertão. Biblioteca Digital Curt Nimuendajú, 2012. Disponivel em: http://www.etnolinguistica.org/doc:17. Acesso em: 27 dez. 2015.

SANTOS, E. M. Da lei do Diretório ao Alvará de 1770: civilizar para o bem do Estado. In: OLIVEIRA, L. E. (org.). A legislação pombalina sobre o ensino de línguas: suas implicações na educação brasileira (1757-1827). Maceió: EDUFAL, 2010. p. 251-272.

SILVA, T. T. da. A produção social da identidade e da diferença. In: SILVA, T. T. da (org.). Identidade e diferença: a perspectiva dos estudos culturais. 15. ed. Petrópolis: Vozes, 2014. p. 73-102.

SOUZA, A. C. P. de. As reformas pombalinas e a produção dicionarística. In: OLIVEIRA, L. E. (org.). A legislação pombalina sobre o ensino de línguas: suas implicações na educação brasileira (1757-1827). Maceió: EDUFAL, 2010. p. 273-298.

WALSH, C. (ed.). Pedagogías decoloniales: prácticas insurgentes de resistir, (re)existir y (re)vivir. Tomo I. Quito, Ecuador: Ediciones Abya-Yala, 2013.

WALSH, C. Gritos, grietas y siembras de vida: Entretejeres de lo pedagógico y lo decolonial. In: WALSH, C. (ed.). Pedagogías decoloniales: prácticas insurgentes de resistir, (re)existir y (re)vivir. Tomo ll. Quito, Ecuador: Ediciones Abya-Yala, 2017. p. 17-45.

Endereços para correspondência: Rua União, 470, Cond. Doce Vida Parque, Casa 55, 49100-000, São Cristóvão, Sergipe, Brasil; profa.valeriaoliveira@gmail.com 